\title{
BMJ Open Medicines shortages in Pakistan: a qualitative study to explore current situation, reasons and possible solutions to overcome the barriers
}

\author{
Muhammad Atif, ${ }^{\oplus 1}$ Iram Malik, ${ }^{\oplus 1}$ Irem Mushtaq, $^{2}$ Saima Asghar ${ }^{1}$
}

To cite: Atif M, Malik I, Mushtaq I, et al. Medicines shortages in Pakistan: a qualitative study to explore current situation, reasons and possible solutions to overcome the barriers. BMJ Open 2019;9:e027028. doi:10.1136/ bmjopen-2018-027028

- Prepublication history and additional material for this paper are available online. To view these files, please visit the journal online (http://dx.doi. org/10.1136bmjopen-2018027028).

Received 02 0ctober 2018 Revised 05 July 2019 Accepted 17 July 2019
A) Check for updates

(C) Author(s) (or their employer(s)) 2019. Re-use permitted under CC BY-NC. No commercial re-use. See rights and permissions. Published by BMJ.

${ }^{1}$ Department of Pharmacy, Islamia University of Bahawalpur, Bahawalpur, Pakistan

${ }^{2}$ Department of Education, Islamia University of Bahawalpur, Bahawalpur, Pakistan

Correspondence to Dr Muhammad Atif; pharmacist_atif@yahoo.com

\section{ABSTRACT}

Objective This study was conducted to assess current situation of medicines shortages in Pakistan and to identify its impact, reasons and possible solutions to overcome the barriers.

Design A qualitative study.

Setting The study was conducted between May 2018 and July 2018 in three cities of Pakistan including Islamabad, Karachi and Bahawalpur, depending on the availability of most relevant key informants.

Participants Health regulators, pharmaceutical manufacturers, pharmaceutical distributors and pharmacists.

Primary and secondary outcome measure Study primarily explored current situation, reasons and potential solutions of medicines shortages in Pakistan. Secondary outcome was the issue of particular brand shortage. Method Semistructured interviews were conducted. Sample size was determined by using saturation point criteria. Convenient sampling techniques were used to recruit the participants. The interviews were audiorecorded and transcribed verbatim. Data were analysed using inductive thematic analysis.

Results A total of 41 stakeholders including 12 health regulators, 6 pharmaceutical manufacturers, 8 pharmaceutical distributors and 15 pharmacists participated in this study. Data analysis yielded 4 themes, 16 subthemes, 51 categories. Essential and life-saving medicines were in short supply. The major reasons of short supply of medicines were active pharmaceutical ingredient and raw material availability issues, lack of traditional distribution system and sudden demand fluctuation. Among proposed solutions, three most common were the facilitation and regulation of manufacturers, reasonable price fixation and improvements in the inventory control system.

Conclusion Medicines were short in supply, and this may have clinical and financial impact on the patients in Pakistan. There were multiple and complex reasons of medicines shortages. Mandatory government leadership is required to resolve the issue on priority basis for improving the access of medicines to the patients.

\section{BACKGROUND}

According to the WHO, the availability of safe, effective and quality essential medicines is fundamental to achieve highest standard

\section{Strengths and limitations of this study}

- This was more likely the first qualitative study undertaken to explore the evidence-based reality of the medicines shortages crisis in Pakistan. This will aid policymakers in the development and pursuance of standard protocols to overcome medicines shortages.

- The study population was chosen to give a thorough representation of stakeholders involved in the Pakistani pharmaceutical supply chain.

- This study provided a strong base for the future researchers to better quantify and understand the factors responsible for triggering medicines shortages.

- Some important stakeholders such as patients and physicians were not included because the study was focused towards the supply side of medicines only.

of human health. ${ }^{1}$ However, frequent medicines shortages have been documented from high-income, middle-income and low-income countries. $^{2}$ In 2017, the WHO stated that almost 2 billion people have no access to basic medicines ${ }^{3}$ causing inferior patient care and costly financial implication. The WHO described medicine shortage as the supply of medicines, health products and vaccines identified as essential by the health system is considered to be insufficient to meet public health and patient needs'. While according to the US Food and Drug Administration (FDA), medicine shortage means a timeframe when the demand or estimated demand for the medicine excels the supply of the medicine. ${ }^{5}$ Medicines shortages is not a newfangled issue, but the scope and extent has aggravated over recent years. ${ }^{6}$ The American Society of Health-System Pharmacists (ASHP) reported that by the end of 2017 , 146 medicines (that has been increased to 224 medicines by the end of June 2018) were in short supply. ${ }^{7}$ In 2018, a Canadian report revealed that there were shortages of approximately 1000 medicinal products annually. ${ }^{8}$ 
The reports from Europe, Australia, Africa, China, Brazil, Fiji and Israel also indicated that medicines shortages were experienced on a regular basis and the trend has been growing rapidly. ${ }^{9-15}$

Medicines shortages represent a notable public health hazard, affecting any category of medicine (generic, paediatric, orphan, biologic, radiopharmaceuticals and so on). ${ }^{16}$ Medicines shortages have generated significant healthcare barriers and its consequences involve therapeutic differences, safety issues (compromised outcomes, medication errors, death and so on) and financial ramifications (higher hospital expenses, increased labour costs, increased cost for patients and so on). ${ }^{17-20}$ Beside this, wholesalers, distributors and producers may experience reduced profit, bad reputation and unhealthy relationship with the clients and authorities. ${ }^{21}{ }^{22}$ There are multifarious and diverse causes of the medicines shortages which differ from region to region. The elements contributing to an interruption in the availability of medicines summarised in WHO and ASHP reports include: (1) manufacturing problems and regulatory issues; (2) voluntary recalls; (3) raw or bulk materials supply issue; (4) alternation in product formulation or manufacturer; (5) limited drug production, supply and allocation; (6) industry consolidations; (7) manufacturers decisions and economics; (8) natural disasters; (9) fragmented demand and shifts in clinical practice; (10) grey market; (11) poor inventory control; (12) non-traditional distributors and (13) restricted drug product distribution and allocation. ${ }^{21723}$

Pakistan, a low middle-income country, is very likely to experience medicines shortages, where lesser proportion of the total healthcare budget is allocated for medicinal products and medical appliances. ${ }^{24}$ Pakistan has a typical pharmaceutical supply system. Medicines manufactured in pharmaceutical industries are relocated to distributors and wholesalers, stocked at retail setups or healthcare institutes, prescribed by medical doctors, dispensed at pharmacies or medical stores and eventually provided to and taken by the consumers. ${ }^{25}$ The import of raw material, manufacture, storage, distribution and sale of medicines in the country are controlled under the Drugs Act, 1976 (XXXI of 1976). The implementation of the Drugs Act, 1976 is ensured by the Drug Regulatory Authority of Pakistan (DRAP) (established under the DRAP Act, 2012).$^{25}{ }^{26}$ DRAP has a committee on availability of life-saving drugs that specifically deals medicines shortages. Despite the presence of a regulatory authority in Pakistan, medicines shortages are triggered by persistent policy gap between the health sector and the pharmaceutical industry, lack of implementation of existing policies, hasty process of registration, failure to regulate price, lack of online notification system and inadequate sentencing practices for non-compliant stakeholders. ${ }^{27-29}$ Different reports from Pakistan revealed that there were severe shortages of antituberculosis medicines, cough and cold medicines, thyroid regulating medicines, neurological disorders medicines, hepatitis medicines and orphan medicines due to regulatory and supply side hurdles. ${ }^{30-33} \mathrm{In}$ a Pakistani study, 55\% physicians and pharmacist working in the tertiary care hospitals of Karachi responded that they have faced shortages of various brands of medicines. According to the study, $89 \%$ physicians and $93.2 \%$ pharmacists reported that medicines shortages led to adverse effect on treatment including treatment delay, complications of treatment, substandard treatment, prolonged hospital stay, increase treatment cost and even death of the patient. ${ }^{34}$

The International Pharmaceutical Federation recommended country-specific investigations to explore the contributing factors and possible solutions to prevent medicines shortages. ${ }^{35}$ To date, evidence-based research data on medicines shortages is lacking and very limited studies are conducted in Pakistan. Even though, in 2017, Fatima and Khaliq quantitatively investigated this issue and explored the views of physicians and pharmacists. ${ }^{34}$ But according to the grey literature, medicines shortages in Pakistan were mainly linked to regulatory and supply side issues, and major stakeholders involved were healthcare regulators and pharmaceutical manufacturers. ${ }^{30} 31333637$ However, as of this date, none of the study from Pakistan appeared to gain the perspective of these important stakeholders. Moreover, despite the higher prevalence of particular brand shortage as compared with generics, ${ }^{34}$ there was dearth of data regarding the issue of particular brand shortage and its associated factors. Therefore, this study was conducted to fill the research gap and provide detailed multiperspective understanding of medicines shortages at different levels in the supply chain. We emphasised on exploring the intricacies of the medicines shortages crisis through a qualitative lens for the very first time in Pakistan to identify the underlying reasons and potential solutions to overcome the barriers. Beside this, phenomena of particular brand shortage were also taken into account as a secondary objective.

\section{METHOD}

\section{Study setting}

Pakistan is a South Asian country. This study was conducted in three cities of Pakistan including Islamabad, Karachi and Bahawalpur, depending on the availability of most relevant key informants. Islamabad is the capital territory of Pakistan while Karachi is the most populous and largest city of the country. Bahawalpur is the main city of the southern Punjab, Pakistan. In Pakistan, the Ministry of National Health Services, Regulations and Coordination regulate health services including supply of medicines. Medicines shortages are dealt (by subdepartments) on a national level by the DRAP (Islamabad) and on district levels by the health department located in each district (figure 1). In this study, health regulators were recruited from the DRAP and the health department (Bahawalpur). Most of the multinational pharmaceutical companies have their head offices in Karachi. Consequently, representatives of pharmaceutical companies were recruited from Karachi. Almost all of the pharmaceutical companies have their distribution setup in Bahawalpur. Therefore, 


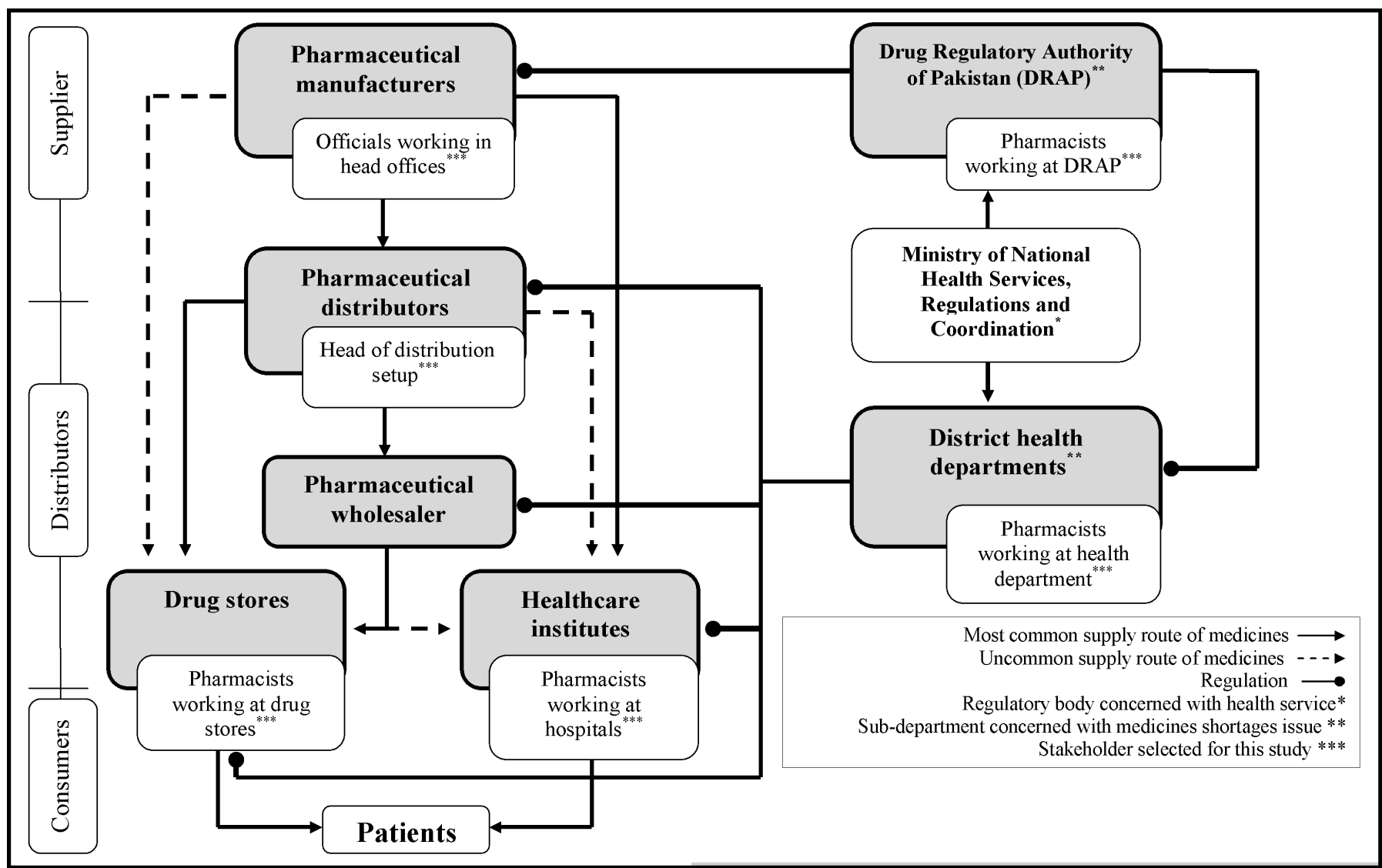

Figure 1 Tiers of pharmaceutical supply chain in Pakistan and key stakeholders included in the study.

head of distribution setups were recruited from Bahawalpur. Pharmacists working in the Civil Hospital, the Bahawal Victoria Hospital and community pharmacies (drug stores) were recruited from Bahawalpur (figure 1).

\section{Study outcomes}

The primary objective of this study was to explore the current situation and reasons of medicines shortages along with the possible solutions to overcome the barriers. Moreover, part of this study was focused to explore the issue of particular brand shortage.

\section{Study design and stakeholders selection}

A qualitative study design was adopted. This methodology was selected based on the nature of the topic because this issue needed to be explored deeply in Pakistan rather than merely the quantification of medicines shortages. To achieve the study objectives, semistructured interviews were conducted using a pilot-tested interview schema. Most relevant key informants were decided based on existing literature, ${ }^{1038} 39$ and then interviewees were selected conveniently (figure 1). All stakeholders were invited to participate in the study through telephone call, and further information regarding the study was provided to them via email on demand. Those who consented to participate in the study were face to face interviewed except the representatives of pharmaceutical manufacturers who were interviewed via telephone call.
The participants were interviewed at a place convenient to them. The sample size was determined by using the saturation point criteria. ${ }^{40}$

\section{Data collection and interview schema}

Data were collected in stages from May to July 2018. Health regulators from the DRAP and the representative of pharmaceutical manufacturers were interviewed in May 2018. In June 2018, regulators from the health department of Bahawalpur and the head of pharmaceutical distributors participated in the study. Hospital and community pharmacists were interviewed in July 2018. Interview schema was constructed for each stakeholder after reviewing literature and authors' experiences (see online supplementary files 1-4). ${ }^{10} 3839$ The interview schemas were modified by preinterviews with one representative each from the four groups. Final interview schemas included questions regarding basic information about the interviewees and their organisation, overall scenario of medicines shortages, underlying reasons and potential solutions and factors contributing to the shortage of particular brand of medicines.

\section{Data analysis}

Audiorecorded interviews were analysed using inductive thematic analysis. All the interviews were conducted in Urdu; the national language of Pakistan and then audiorecords were listened several times and transcribed verbatim by IM. Transcripts were carefully translated in English by IM, and forward-backward translation method 
was applied on some of the transcripts $(20 \%)$ to check the accuracy of data. ${ }^{41}$ Translations were studied again and again to get familiarise with the data. Coding was done manually by all authors. Relevant words, phrases and sentences indicating the study objectives were labelled, and initial inductive codes were generated to split the data into individually coded segments. Codes emerging from early interviews shaped a coding taxonomy that was used to evaluate subsequent interviews. Initial coding was followed by focused coding. In focused coding, the relationship between different initial codes was explored on the basis of similarity, difference, frequency, sequence, correspondence and causation. Final inductive codes were grouped into meaningful categories by IM, IMU and MA. Themes and subthemes were created by bringing several categories together to conceptualise the data. Transcripts, codes and categories were reviewed recursively before producing final themes. Quantification (counting the frequency of each code) and tabulation were also used to improve the reliability of the findings. ${ }^{38} 42$ Each answer was quantified once per respondent, and the finding indicated by the majority of the respondents was considered as an important finding. Research team had regular meetings and discussions to cross-check that they had a common perspective and understanding of the generated categories. In case of any conflict or disagreement, final verdict was given by MA (senior author). Hierarchy of the findings was decided on the basis of the calculated frequency in descending order, and then results were written to produce final report.

\section{Ethical approval}

Verbal consent to participante in the study was taken from all the stakeholders. Participants were encouraged to read the purpose of the study and the confidentiality statement before starting the interview. The names of the respondents were not disclosed in the study and the audio recordings were saved in the password protected computer. Respondents were also given the freedom to skip any question or quit the interview at any time.

\section{Patient and public involvement}

Patients and public were not involved in planning or conducting this study.

\section{RESULTS}

\section{Participant characteristics}

Among all the interviewees invited to participate in the study, five refused ( $11 \%$ refusal rate) to participate because of their busy work schedule and lack of interest in the study. A total of 41 stakeholders were interviewed

Table 1 Respondents characteristics and interview duration

\begin{tabular}{|c|c|c|c|c|c|c|c|c|c|}
\hline Stakeholder & & Gender & Age & $\begin{array}{l}\text { Interview } \\
\text { duration } \\
\text { (min) }\end{array}$ & Stakeholder & & Gender & Age & $\begin{array}{l}\text { Interview } \\
\text { duration } \\
\text { (min) }\end{array}$ \\
\hline \multirow{6}{*}{ Health regulators } & 2 & Male & 30 & 34 & \multirow{3}{*}{$\begin{array}{l}\text { Pharmaceutical } \\
\text { manufacturers }\end{array}$} & 22 & Female & 31 & 32 \\
\hline & 3 & Male & 56 & 27 & & 23 & Male & 52 & 44 \\
\hline & 6 & Male & 38 & 25 & & 26 & Female & 27 & 30 \\
\hline & 7 & Female & 40 & 33 & \multirow[t]{11}{*}{ Pharmacists } & 27 & Female & 26 & 30 \\
\hline & 8 & Male & 55 & 27 & & 28 & Female & 29 & 31 \\
\hline & 9 & Female & 38 & 34 & & 29 & Female & 30 & 30 \\
\hline \multirow{8}{*}{$\begin{array}{l}\text { Pharmaceutical } \\
\text { distributors }\end{array}$} & 13 & Male & 45 & 30 & & 33 & Male & 45 & 36 \\
\hline & 14 & Male & 51 & 33 & & 34 & Male & 29 & 29 \\
\hline & 15 & Male & 55 & 34 & & 35 & Male & 48 & 40 \\
\hline & 16 & Male & 59 & 30 & & 36 & Male & 27 & 45 \\
\hline & 17 & Male & 54 & 38 & & 37 & Female & 26 & 31 \\
\hline & 18 & Male & 62 & 32 & & 38 & Female & 24 & 34 \\
\hline & 19 & Male & 50 & 44 & & 39 & Female & 29 & 38 \\
\hline & 20 & Male & 45 & 24 & & 40 & Female & 26 & 31 \\
\hline
\end{tabular}


Table 2 Theme 1; current situation of medicines shortages in Pakistan

Subtheme Categories and subcategories Quotations

Understanding of the term 'medicines shortages'

Last 1 year trend of medicines shortage

Notification system
Definitions of medicines shortages included:

- Imbalance between the demand and supply or production.

- Inadequate or intermittent supply.

- Unavailability of product at any given time.

- Unavailability for all age groups and entire dosage regimen.

Types of medicines shortages included:

- Generic shortage and brand shortage.

- Simple shortage, high shortage and critically high shortage.
'Drug shortage or medicine shortage is actually a gap between the supply and the demand. If the supply or the manufacturing is less or done less than the demand then the shortage is created.' (Regulator 10)

'All the registered drugs if not adequately supplied in market and which can threaten the patient need, are called shortages.' (Manufacturer 2)

'When any medicine is not available in the market for a particular time due to any interruption in the supply is called as medicine shortage.' (Manufacturer 6)

'When the medicine is not freely available for the patients of all age groups as well as for the entire dosage regimen, it is termed as shortage.' (Pharmacist 10)

'Basically shortages are of two types. One is generic shortage and other is brand shortage. Molecule itself, like if it's all brands are short then this is generic shortage, and other is if any specific known brand is short then it is brand shortage.' (Regulator 3)

We have categorised three categories; number one shortage; number two high shortage; number three critically high shortage. The shortage complaint that is received from any consumer, we issue explanation letter of drug shortage. If the shortage is in more than one city but is available in some cities then we issue the explanation letter of high shortage and if that medicine is dead short in whole country then we issue the explanation letter of critical shortage.' (Regulator 4)

Situations aroused many times during last 12 months

'Yes, number of the times, such type of situation aroused in the market when the drugs were short.' (Regulator 1)

Types of medicines undergoing shortages included:

- Essential medicines (ie, antibiotics and seasonal medicines like antidiarrheal, antiasthmatic, antiallergy, analgesics and antipyretics, etc).

- Life-saving medicines (ie, antiangina and antihyperthyroidism) were short.

- Orphan drugs (eg, penicllamine).

- Controlled drugs (ie, narcotics, sedatives and hypnotics) were short.

There was proper notification system at health regulators level from the chief drugs controller office and sometimes letters are

Lack of proper notification system at manufacturer level

Lack of notification system at distributor level 'Patients also inform us. Some of the notifications are received received from DRAP, so these are our sources of notification....we send notification to manufacturers and their concerned distributors.' (Regulator 8)

'Basically in general, there are two types of medicines, one is essential medicine and other is lifesaving medicine. In essential medicine, it involves all medicines in the market, from analgesic to antibiotics, they are considered to be essential. And other category is lifesaving that include those products which are used in emergency situations.' (Manufacturer 5)

"Orphan drug' is actually a term which indicate a product having very low price and company has no profit in this and very limited companies are manufacturing... some controlled drugs undergo shortages.' (Regulator 8)

'Generally, in Pakistan there is no such trend, but multinationals sometimes do that. When there are high level shortages, means when alternative is not available, then multinationals are bound to notify. But we don't notify when alternative is available in the market.' (Manufacturer 1)

'No, we don't receive or send any notification. Rather manufacturers never inform but one or two companies informed us that medicine is short and its reason is shortage of raw material...' (Distributor 1) 
Table 2 Continued

\begin{tabular}{|c|c|c|}
\hline Subtheme & Categories and subcategories & Quotations \\
\hline \multirow[t]{3}{*}{ Preventive measures } & $\begin{array}{l}\text { Drug regulatory authority of } \\
\text { Pakistan asked, compelled } \\
\text { and prosecuted non-complaint } \\
\text { manufacturers and distributors } \\
\text { to prevent medicine shortages }\end{array}$ & $\begin{array}{l}\text { 'We take preventive measures like if there are limited brands } \\
\text { available, then we encourage other manufacturer to manufacture } \\
\text { that product after taking its registration. Plus those who are not } \\
\text { manufacturing, we pressurise them to resolve their issues... we also } \\
\text { try to facilitate them if they are facing any problem.' (Regulator 3) }\end{array}$ \\
\hline & $\begin{array}{l}\text { Health department conducted } \\
\text { surveillance of the shortage } \\
\text { items and tried to ensure the } \\
\text { availability of alternatives }\end{array}$ & $\begin{array}{l}\text { 'We have developed surveillance system, in which we check; which } \\
\text { medicines are short; which medicines are not supplied and are } \\
\text { short for such time span; whether their alternate is available or not.' } \\
\text { (Regulator 11) }\end{array}$ \\
\hline & $\begin{array}{l}\text { Manufacturers tried to prevent } \\
\text { the shortage of medicines in } \\
\text { market }\end{array}$ & $\begin{array}{l}\text { 'We make plans for the whole year and assure that sufficient product } \\
\text { remain available throughout the year and try to maintain its supply...If } \\
\text { there is shortage of drug even after producing sufficient product then } \\
\text { we check distributors that whether proper supply is maintained or } \\
\text { not.' (Manufacturer } 1 \text { ) }\end{array}$ \\
\hline
\end{tabular}

including 12 health regulators, 6 manufacturers, 8 distributors and 15 pharmacists. Interview duration ranged from 24 to $65 \mathrm{~min}$ with an average duration of $35 \mathrm{~min}$. Among the interviewees, 27 were male and 14 were female. The age of the participants ranged from 26 to 62 years. The respondents' characteristics are given in table 1 .

From a saturated pool of information, four key themes were extracted that is, current situation of medicines shortages in Pakistan, its reasons, possible solutions and the particular brand shortage issue.

Theme 1: current situation of medicines shortages in Pakistan Multiple phrases were used by the stakeholders to describe medicines shortages, including inadequate supply of medicines, an imbalance between the demand and supply or production and unavailability of medicines for particular time period. Almost all the participants said that during the past 12 months, they had seen the situation when medicines were short in the market or in an institute, and according to them, essential, lifesaving, controlled and orphan medicines were short. All the regulators and few manufacturers stated that they had taken measures to prevent medicines shortages issue while distributors declared themselves handicap in doing so. On asking about the notification system, the majority of the regulators informed that they had received or sent notification regarding medicines shortages while none of the manufacturer and distributor reported a proper notification system. Subthemes, categories and exemplar quotations related to theme 1 are given in table 2 .

A list of short medicines reported by the stakeholders during last 12 months is given in table 3 .

\section{Theme 2: reasons of medicine shortages}

Multiple and complex reasons of medicine shortages were indicated by the stakeholders on different levels. On manufacturer level, the majority of the participants indicated that the main reason of medicine shortages were the raw material related issues, including import issues, availability issues, pricing and quota allocation for controlled raw material (37 out of 41respondents) and planning and forecasting gap. On distribution level, the main reason reported by the study participants was the intermittent or inadequate supply of product from the manufacturer's side and the other reason indicated was the biassed distribution of short products. In hospital setting, the majority of the participants described that there was poor inventory management and procurement procedure (27 out of 41 respondents). According to them, the contributing factors in the poor inventory management were a poor demand prediction, poor procurement procedure, pilferage of the medicines and the poor storage conditions. Other issues highlighted by many participants were budget constraints and delayed quality control testing. Based on the market attributes of the product, the low price and low demand were the major reasons of shortage of medicines (26 out of 41 respondents). Subthemes, categories and exemplar quotations related to theme 2 are given in table 4 .

Table 5 shows most common reasons associated with medicines shortages. The most common reason was raw material-related issues and least common was production hurdles.

\section{Theme 3: possible solutions of the medicines shortages}

All the stakeholders provided practical suggestions to alleviate medicines shortages. They recognised the government as having the authority of resolving this issue. The majority of the respondents recommended that the manufacturers should be facilitated, motivated and regulated by the government for the continuous production and supply 
Table 3 List of short medicines

\begin{tabular}{|c|c|}
\hline Category & Short drugs \\
\hline Antiallergy & $\begin{array}{l}\text { Hydroxy hydrochloride, cetirizine, } \\
\text { chlorpheniramine, ketotifen } \\
\text { fumerate, cyclizine, triprolidine, } \\
\text { pseudoephedrine }\end{array}$ \\
\hline Antimicrobial & $\begin{array}{l}\text { Azithromycin, ceftriaxone, } \\
\text { quinine, ethambutol, isoniazid, } \\
\text { acyclovir }\end{array}$ \\
\hline Antihypertensive & $\begin{array}{l}\text { Acetazolamide, metoprolol, } \\
\text { methyldopa, verapamil, nefidipine }\end{array}$ \\
\hline Analgesic & $\begin{array}{l}\text { Acetaminophen, ibuprofen, } \\
\text { flurbiprofen, diclofenac sodium }\end{array}$ \\
\hline Tranquillisers & $\begin{array}{l}\text { Zolpidem tartrate, alprazolam, } \\
\text { diazepam, clobazam }\end{array}$ \\
\hline Anticonvulsant & $\begin{array}{l}\text { Piracetam, phenobarbitone, } \\
\text { phenytoin }\end{array}$ \\
\hline Cardiac drugs & $\begin{array}{l}\text { Isosorbide mononitrate, digoxin, } \\
\text { glyceryl trinitrate }\end{array}$ \\
\hline Digestive system drugs & $\begin{array}{l}\text { Dimenhydrinate, magnesium } \\
\text { sulfate, femotidne }\end{array}$ \\
\hline Antipsychotic & $\begin{array}{l}\text { Clomipramine, bromocriptine, } \\
\text { aripiprazole }\end{array}$ \\
\hline Vaccines & Antisnake, ntirabies \\
\hline Anticancer & Cyclophosphamide, hydroxyurea \\
\hline Antiarthritic & Azathioprine, penicillamine \\
\hline Corticosteroid & Clobetasol \\
\hline Anticoagulant & Transamine \\
\hline Antimigraine & Methylergotamine \\
\hline CNS stimulant & Caffeine \\
\hline Contraceptive & Norethisterone \\
\hline Antihyperthyroidism & Neomarcazole \\
\hline Antihypothyroidism & Thyroxin \\
\hline
\end{tabular}

CNS, central nervous system.

of medicine (28 out of 41 respondents). Other important solutions proposed by most of the participants were the reasonable price fixation (25 out of 41 respondents) and the establishment of reserve system of medicines by the government. On manufacturer level, the availability of backup raw material was the common solution suggested by most of the respondents. Many informants also suggested that manufacturers must ensure the availability of commercially and financially non-viable product on ethical grounds. According to the majority of the participants, the most frequently proposed solutions on the distribution level were the development of unbiassed distribution system, strong and healthy interaction of distributers with manufactures, supply chain management, good storage practices and increased human and monetary resources. In healthcare institutes, improvement in the inventory control system (19 out of 41 respondents), extra budget allocation and strengthening of the pharmacist role were some of the possible solutions to prevent the medicines shortages issue. Subthemes, categories and exemplar quotations related to theme 3 are given in table 6 .

Table 7 shows most common solutions to overcome medicines shortages. Among the most common solutions, 28 participants stated that manufacturers should be facilitated, motivated and regulated to resolve the issue, while 15 participants stated that there should be generic prescribing and improvement in the distribution system to overcome the medicines shortages issue.

\section{Theme 4: particular brand shortage issue}

Multiple reasons of particular brand shortage were reported by the stakeholders. Among these, lack of traditional distribution system (32 out of 41 respondents), accidental and seasonal demand increase (30 of the 41 respondents), production hurdles (17 out of 41 respondents), irrational prescribing (22 out of 41 respondents), limited number of registered companies for a particular active pharmaceutical ingredient and batch recall due to quality and stability issues were the major reasons reported by the study participants. The suggestion for preventing particular brand shortages included; promotion of traditional distribution system, promotion of generic prescription (15 out of 41 respondents) and issuance of registration of multiple brands of same active pharmaceutical ingredient to other manufacturers. The patient-related factors influencing the demand of a particular brand were their preference to doctor prescription, lack of knowledge and awareness and trust on specific brand and psychological acceptance. The reasons of prescribing a particular short brand by the doctors included; influence of the promotional marketing strategies by the pharmaceutical companies (34 out of 41 respondents), reliability and confidence of doctors on particular brand (23 out of 41 respondents) and lack of information about the shortage. Subthemes, categories and exemplar quotations related to theme 4 are given in table 8 .

Based on study findings, figure 2 summarises reasons and overall solutions of medicines shortages in Pakistan.

\section{DISCUSSION}

Medicines shortages is a frequently rising global phenomena posing a significant health risk to the patients and burdening the healthcare system. ${ }^{15} 3943$ The WHO stated medicines shortages as a very less-investigated issue in low-income and middle-income countries, ${ }^{2}$ and this is the first qualitative study to gain in-depth understanding of complex and multifaceted medicines shortages issue in Pakistan. In this study, 4 themes, 16 subthemes and 51 categories emerged. The themes highlighted the current scenario of medicines shortages in Pakistan, its reasons and possible solutions and particular brand shortage issue.

In this study, different types of terminologies were used by the participants to describe the medicines shortages, and all terminologies were comparable with the definitions of medicines shortages given by the WHO and FDA.$^{45}$ For example, our respondents stated that medicine shortage is the gap 
Table 4 Theme 2; reasons of medicine shortages

\begin{tabular}{|c|c|c|}
\hline Subtheme & $\begin{array}{l}\text { Categories and } \\
\text { subcategories }\end{array}$ & Quotations \\
\hline \multirow[t]{5}{*}{$\begin{array}{l}\text { Manufacturer } \\
\text { level }\end{array}$} & $\begin{array}{l}\text { Raw material related } \\
\text { issues included: } \\
\text { Raw material import } \\
\text { hurdles. } \\
\text { - Lack of resources of } \\
\text { raw material. } \\
\text { High cost of raw } \\
\text { material. } \\
\text { - Raw material quota } \\
\text { issue. }\end{array}$ & $\begin{array}{l}\text { 'One of the reasons is the raw material import. Sometimes there is hurdle, like raw material } \\
\text { is not cleared by customs or other processes due to which their supply chain is stopped } \\
\text { which result in the discontinuation of the product.' (Regulator } 8 \text { ) } \\
\text { 'There is genuine problem that raw material sources are very rare in the world or are } \\
\text { finished. Only there are few raw material manufacturers and they also produce material in } \\
\text { limited quantity that worldwide supply chain got affected.' (Regulator 12) } \\
\text { 'The second factor is price, there are many products whose raw materials are very costly... } \\
\text { when manufacturer failed to get appropriate price then he tries to avoid manufacturing that } \\
\text { product in which his profit margin is very low.' (Distributor 1) } \\
\text { 'There are some controlled substances that have quota for specific manufacturing and } \\
\text { they could not get more than this. So sometimes due to raw material constraints, a gap is } \\
\text { created between supply and demand.' (Regulator 10) }\end{array}$ \\
\hline & Planning gap & $\begin{array}{l}\text { 'There are the major chances that companies do wrong forecasting of the market } \\
\text { demand...there is some planning gap. Planning is not very efficient which leads to } \\
\text { shortages.' (Distributor 5) }\end{array}$ \\
\hline & Limited resources & $\begin{array}{l}\text { 'Manufacturers don't have enough resources. In resources there could be human resources } \\
\text { or material resources or machinery resources. So in this situation there is shortage.' } \\
\text { (Manufacturer 4) }\end{array}$ \\
\hline & Electricity crisis & $\begin{array}{l}\text { 'There are energy crises that is, earlier the energy was supplied to firms for } 24 \text { hours but } \\
\text { now it is reduced very much; so, due to this their production is suffering very much.' } \\
\text { (Regulator 2) }\end{array}$ \\
\hline & $\begin{array}{l}\text { Lack of qualified } \\
\text { personnel }\end{array}$ & $\begin{array}{l}\text { Many personnel are not qualified in industries that lead to production hurdles ... they } \\
\text { should have qualified people, so that the probability of production breakdown became } \\
\text { less.' (Manufacturer 2) }\end{array}$ \\
\hline \multirow[t]{2}{*}{$\begin{array}{l}\text { Distribution } \\
\text { level }\end{array}$} & $\begin{array}{l}\text { Intermittent or } \\
\text { inadequate supply from } \\
\text { the manufacturer's side }\end{array}$ & $\begin{array}{l}\text { 'Their main reason is that distributors are not receiving supply. Manufacturers are not } \\
\text { sending stock according to their demand so this is the main reason... Wholesalers and } \\
\text { distributors are bound that if they don't get supply then obviously they could not provide } \\
\text { to others. If manufacturer is not supplying according to his demand then he is helpless.' } \\
\text { (Regulator 8) }\end{array}$ \\
\hline & $\begin{array}{l}\text { Biassed distribution } \\
\text { monopoly }\end{array}$ & $\begin{array}{l}\text { 'Sometimes, when distributors are aware that any particular product is short in the market } \\
\text { then they do not distribute equally...They forward it to specific people and in this way } \\
\text { shortage becomes severe.' (Distributor 4) } \\
\text { 'When the demand of the drug is more in any other area then distributors supply medicines } \\
\text { of one area to other area where the price is high. So the main reason of shortage is the } \\
\text { supply of medicines from one province to another province.' (Regulator 10) }\end{array}$ \\
\hline \multirow[t]{4}{*}{$\begin{array}{l}\text { Healthcare } \\
\text { institute level }\end{array}$} & $\begin{array}{l}\text { Poor inventory } \\
\text { management and } \\
\text { procurement procedure } \\
\text { included: } \\
\text { Poor demand } \\
\text { prediction. } \\
\text { Poor procurement } \\
\text { procedure. } \\
\text { Pilferage of } \\
\text { medicines. }\end{array}$ & $\begin{array}{l}\text { 'There is problem in their demand prediction. When they don't purchase according to } \\
\text { demand then there will be shortage in future.' (Distributor 1) } \\
\text { 'The procurement planning in not proper that how much you have to procure medicine? } \\
\text { When you have to start the procurement cycle to purchase timely and efficiently?' } \\
\text { (Regulator 10) } \\
\text { 'One reason of shortage in hospitals is the pilferage of medicines. It is a big reason due to } \\
\text { which patients don't get their medicines.' (Regulator 2) }\end{array}$ \\
\hline & Budget constraints & $\begin{array}{l}\text { 'There are some problems related to their budget. In our government hospitals the average } \\
\text { of the patients is very high but their budget is less accordingly...due to which shortage is } \\
\text { created many times.' (Regulator 10) }\end{array}$ \\
\hline & Supply issue & $\begin{array}{l}\text { 'There is issue from distributor's side that they are not supplying properly in hospitals. They } \\
\text { are not providing the quantity demanded by hospital, due to which shortage happens.' } \\
\text { (Pharmacist 1) } \\
\text { 'In government hospitals, medicine is purchased in large amount because there is } \\
\text { consumption in bulk quantity. But if the company is not producing in bulk according the } \\
\text { demand of the government and fail to timely fulfill the demand then this could lead to } \\
\text { shortages.' (Distributor 7) }\end{array}$ \\
\hline & $\begin{array}{l}\text { Delayed quality control } \\
\text { testing }\end{array}$ & $\begin{array}{l}\text { '...if the sample became late from Drug Testing Laboratory (DTL) then there could be drug } \\
\text { shortage in hospital because they don't release the batch for the patient use unless they } \\
\text { get the pass report from DTL...' (Pharmacist 10) }\end{array}$ \\
\hline
\end{tabular}


Table 4 Continued

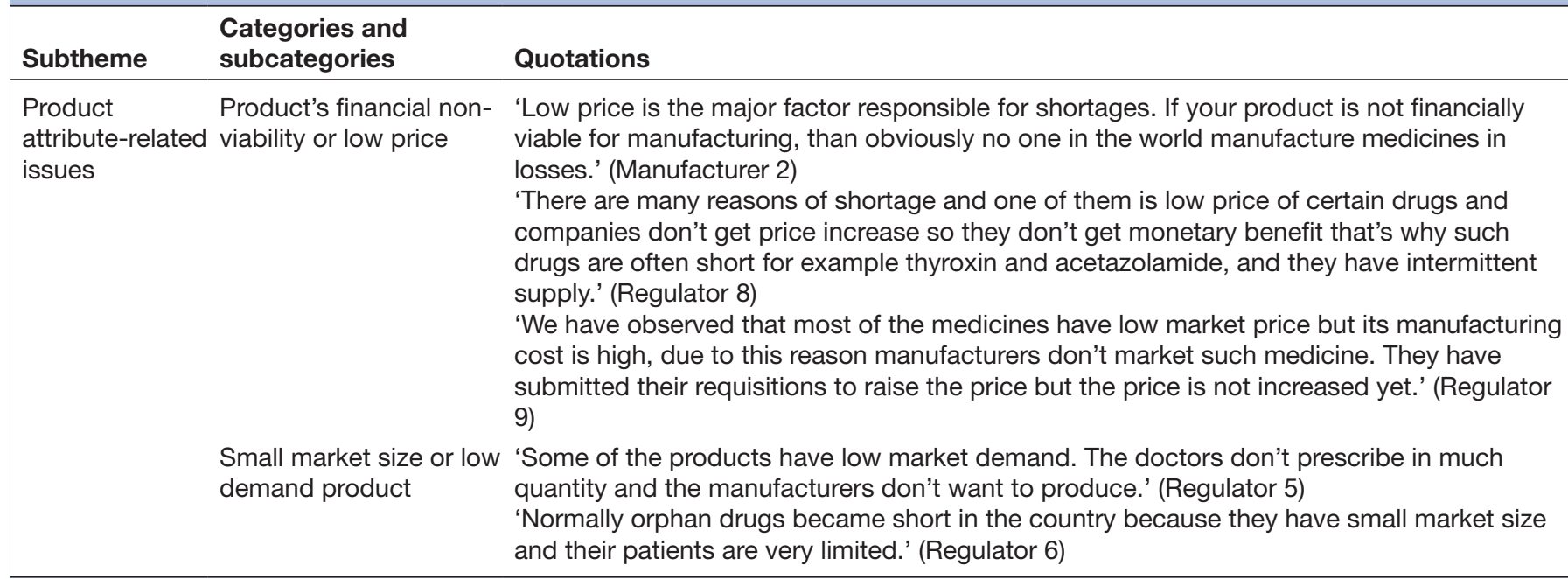

between the demand and supply or production, unavailability of product at any given time and unavailability of medicines for all age groups and entire dosage regimen. Likewise, a European study stated that medicines shortages could be expressed as demand and supply imbalance or interrupted supply or the unavailability of medicines to satisfy the patient needs. ${ }^{44}$ According to the results of our study, shortages of essential medicines, life-saving medicines and orphan medicines were frequent during the last 1year in Pakistan. Few previous grey literature reports also indicated shortage of orphan and essential medicines in the country. ${ }^{30-32}$ The gap in the essential medicine access is driven by inefficient Pakistani healthcare system and pharmaceutical regulations, which necessitates multidimensional integrated approaches to ensure the availability of medicines. ${ }^{45}$ These findings were concurrent with the typology of medicines shortages presented by the Chinese and European studies. ${ }^{10} 43$

Our respondents elaborated that no single aspect can be considered as a reason of medicines shortages. Among multiple reported reasons, the major reason was raw material-related issues including its import hurdles, unavailability, high cost and restricted quota allocation.

\begin{tabular}{ll}
\hline $\begin{array}{l}\text { Table } 5 \text { Most common reasons behind medicines } \\
\text { shortages (mentioned by } \geq 17 \text { respondents) }\end{array}$ \\
\hline Reasons of shortage & $\mathrm{n}^{*}$ \\
Raw material-related issues & 35 \\
Lack of traditional distribution system & 32 \\
Sudden demand fluctuation & 30 \\
Poor inventory management and procurement & 27 \\
procedure & \\
Product's financial non-viability or low price & 26 \\
Marketing influenced prescribing & 22 \\
Production hurdles & 17
\end{tabular}

*' $n$ ' refers to the frequency of reported reason among total respondents. Each answer was quantified once per respondent.
According to a report, medicines shortages occurred in the USA due to interruption in the raw material supply because $80 \%$ of it was imported from abroad. ${ }^{17}$ The reasons of unavailability of raw material could be limited suppliers or manufacturers of raw material, political conflicts leading to import hurdles, regulatory restrictions on the import and allocation of controlled substances, long delivery time, issues in the extraction of raw material due to the environmental changes, complex production chain, quality issues and issues in the transport and storage. ${ }^{172138}$ In Pakistan, most of the raw materials and active pharmaceutical ingredient are imported from India, China, Europe, North America and other countries. $^{25}$ According to news reports, increase in the value of the US dollar as compared with Pakistani rupee resulted in increased cost of raw material and subsequent shortages of life-saving medicines. ${ }^{3146}$ Beside this, quota of controlled substances in Pakistan is allocated by the Narcotics Control Board in consultation with DRAP. ${ }^{3647}$ The stringent control on controlled substances for example, ephedrine, pseudoephedrine and delay in the quota announcement had created the medicines shortages in the country. ${ }^{36} 37$

Poor inventory management and procurement procedure was another reason of medicines shortage in Pakistani hospitals. Many previous studies including a Pakistani study highlighted that inventory mismanagement was one of the major factors undermining the medicines access in hospitals. ${ }^{1048}$ According to the reports, contributing factors in the poor inventory management could be inadequate budget, physicians preferences, limited information sharing and lack of active role of pharmacist, ${ }^{49}$ while poor procurement could be due to delays in tendering, absence of contractors and incapability of the suppliers to fulfil demand. ${ }^{2}$ In view of our study participants, the second major reason of medicines shortages in the hospital context was budget constraints. Likewise, a previous study revealed that inadequate funding or poor budget management was a reason of poor availability 
Table 6 Theme 3; possible solutions of medicines shortages

\begin{tabular}{|c|c|c|}
\hline Subtheme & $\begin{array}{l}\text { Categories and } \\
\text { subcategories }\end{array}$ & Quotations \\
\hline \multirow[t]{3}{*}{$\begin{array}{l}\text { Government } \\
\text { level }\end{array}$} & $\begin{array}{l}\text { Manufacturers } \\
\text { should be } \\
\text { facilitated, } \\
\text { motivated and } \\
\text { regulated }\end{array}$ & $\begin{array}{l}\text { 'Government should educate manufacturers; should guide them; should solve their genuine issues; } \\
\text { and if anyone is not obeying from regulation point of view then they must be punished and they should } \\
\text { bound manufacturer so that shortage could be prevented.' (Regulator } 8 \text { ) } \\
\text { 'Government should facilitate manufacturer by timely approving the quota of raw material according to } \\
\text { demand and should review price of medicines. If any product is in hardship and by increasing its price } \\
\text { it can come back into market then there is no vain.' (Manufacturer } 1 \text { ) } \\
\text { 'And regulatory authorities need to conduct discussions on factual basis rather than theoretical } \\
\text { basis.... working together of regulatory body and the industry could be the one of the solution to really } \\
\text { ensure medicines availability... Industry association or representative body and regulatory bodies } \\
\text { should come up with the pragmatic solutions on the basis of each event.' (Manufacturer 2) }\end{array}$ \\
\hline & $\begin{array}{l}\text { Price negotiation } \\
\text { and fixation }\end{array}$ & $\begin{array}{l}\text { 'The price of some critically needed drugs whose price is fixed very earlier and is not updated yet } \\
\text { and the firms are now at a point that they are facing losses so they demand price re-fixation for that } \\
\text { product. So we have to identify such molecules that are critically needed and for this we have to keep } \\
\text { special mechanism of price fixation.' (Regulator 5) } \\
\text { 'There should be reasonable price margin so that manufacturer could produce more and more } \\
\text { medicines. When they don't get enough profit then they stop giving attention towards low-cost } \\
\text { product and they only do the formality by manufacturing limited quantity of that item to maintain their } \\
\text { registration. So, manufacturers need to be motivated for the low-cost short items through reasonable } \\
\text { price fixation' (Distributor 5) }\end{array}$ \\
\hline & $\begin{array}{l}\text { Backup stock } \\
\text { maintenance }\end{array}$ & $\begin{array}{l}\text { 'Government should maintain good stock. They should set their inventory levels.... There could be a } \\
\text { very good system for the lifesaving and critically needed drugs in which government buy the stock and } \\
\text { then sale forward on less market price.' (Manufacturer 3) }\end{array}$ \\
\hline
\end{tabular}

Manufacturer Raw material 'Manufacturer must keep their raw material inventory maximum so that they could fill manufacturing level availability should be assured gap of any short product.' (Regulator 8)

Ensure product 'They should not consider profit in every product. There are some products that are profitable and availability as ethical there are some that have low profit margin or zero margin so they must provide them in view of patient responsibility interest as an ethical business.' (Regulator 5)

Qualified personnel 'There are mostly less number of qualified people in the production unit, workers are working there availability in the from years and they are skilled, so they don't want to appoint any pharmacist or production officer. If premises any qualified person will control the production there then the issues will minimize and prospecting will be improved.' (Pharmacist 9)

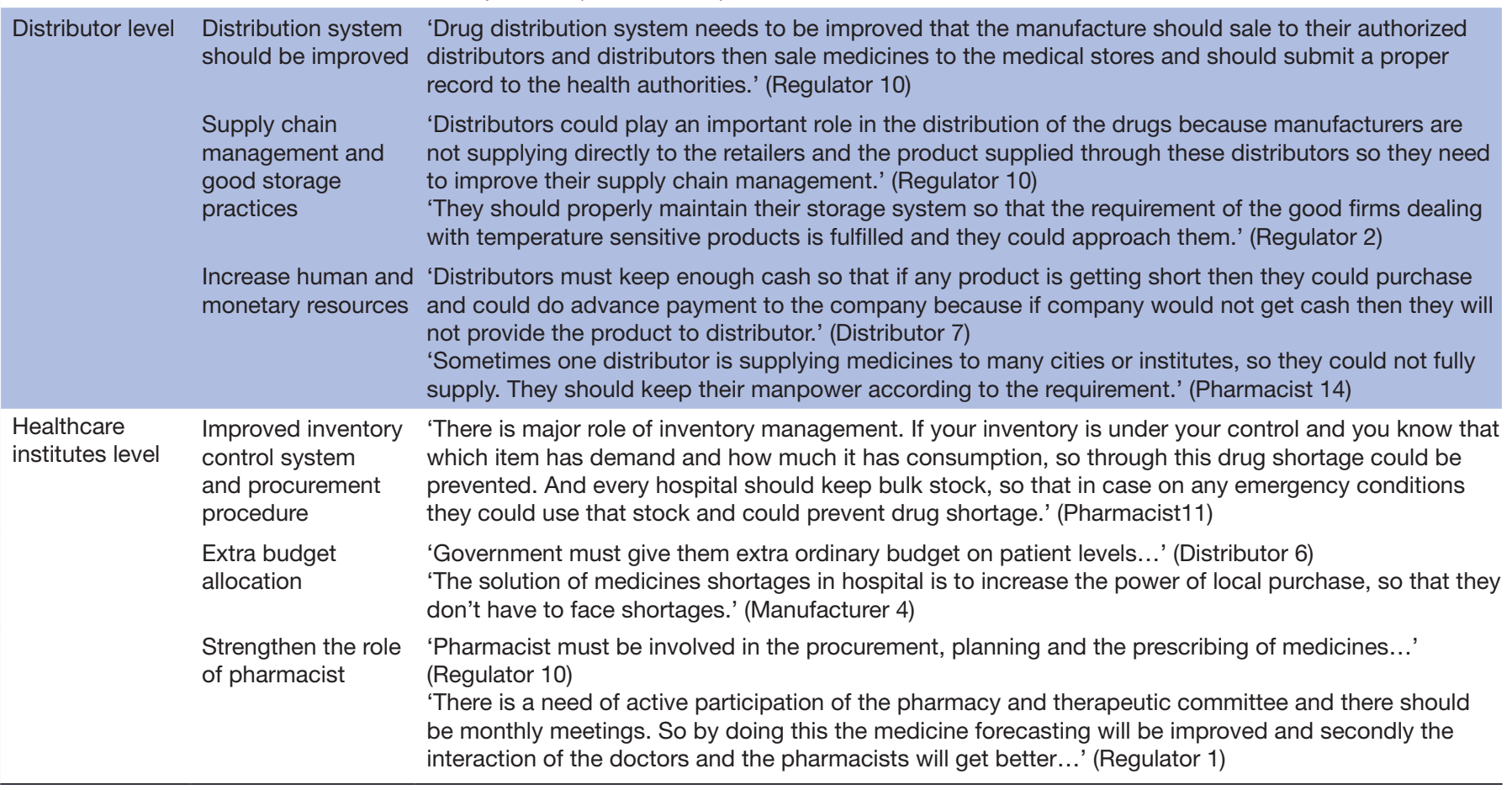

of medicines in Pakistani hospitals. ${ }^{45}$ In Pakistan, the amount allocated for medicines in the public healthcare centres is below the critical threshold of $\$ 2$ per capita per year suggested by the WHO to prevent medicines shortages. ${ }^{51}$ Beside this, inefficient budget management further exacerbates this issue in the country. ${ }^{45}$ Multiple 
Table 7 Most common solutions of medicines shortages (mentioned by $\geq 15$ respondents)

\begin{tabular}{ll}
\hline Possible solutions of medicines shortages & $\mathrm{n}^{*}$ \\
$\begin{array}{l}\text { Manufacturers should be facilitated, motivated } \\
\text { and regulated }\end{array}$ & 28 \\
$\begin{array}{l}\text { Price negotiation and fixation by the regulatory } \\
\text { bodies }\end{array}$ & 25 \\
Improved inventory control system & 19 \\
Improved distribution system & 15 \\
Promotion of traditional distribution system & 15 \\
\hline Generic prescribing & 15 \\
\hline
\end{tabular}

*' $n$ ' refers to the frequency of reported solution among total respondents. Each answer was quantified once per respondent.

factors contribute to inefficient budget management, including inadequate demand prediction, poor procurement, medicine pilferage and unavailability or lack of active participation of pharmacists. ${ }^{45}$

Product's financial non-viability or low price was also considered as major reason of medicines shortages by our respondents, and this finding is in accordance with the findings of studies from Belgium, France and China. ${ }^{10} 39$ Low price issue may further leads to parallel distribution, grey market, permanent discontinuation of product due to lack of market attractiveness and thus complicating the medicines shortage issue. ${ }^{38}{ }^{39}$ In Greece, 203 products were withdrawn from the market due to low market price. ${ }^{52}$

The study participants viewed the government as having the authority to resolve the medicines shortages issue. Among the proposed solutions, the most important were the facilitation and regulation of manufacturer, reasonable price fixation and improved inventory control system in hospitals. The government should immediately regulate and bind the manufacturers to ensure the availability of medicines and should resolve their issues. The FDA has also considered the regulation and facilitation of manufacturers as one of the short-term strategic plan for preventing and mitigating medicines shortages. ${ }^{53}$ Besides regulation and facilitation of the manufacturers, reasonable price fixation was proposed as another short-term solution of medicines shortages in Pakistan. The WHO has also emphasised fair pricing for both the supplier and consumer to prevent medicines unavailability. ${ }^{2}$ Matching suggestion was also proposed by the participants of a Chinese study, in which they quoted a notion that 'a higher price but available in the market' is better than 'a lower price but no access'. ${ }^{10}$ Reasonable pricing may well persuade pharmaceutical manufacturers to increase their production and supply. The governments should negotiate with the patent holders on priority basis to reach a mutually acceptable price agreement ${ }^{2}$ after carefully considering different price components, including registration, postapproval activities, importation cost of raw and packaging materials, transportation charges, direct and indirect manufacturing costs and maintenance costs, 3954 especially in Pakistan, where medicines shortages were the consequences of years of deadlock between DRAP and the pharmaceutical manufacturers over the pricing of medicines. $^{31-33}$ However, recently in January 2019, taken into account the current situation of medicines shortages in the country and its associated complex reasons such as the $30 \%$ devaluation of Pak Rupee against the US dollar and subsequent increased pricing of raw and packaging materials, DRAP has notified $9 \%-15 \%$ increase in the prices of life-saving and other medicines, respectively. ${ }^{46}$ This corrective measure is expected to immediately address medicines shortages conundrum within the country.

To prevent medicines shortages in hospitals, participants of this study suggested the improvement in the inventory management as a solution through active participation of pharmacists in forecasting, procurement and product selection. Unfortunately, there is limited scope of pharmacy practice and lack of pharmacist acceptance in the Pakistani healthcare settings. ${ }^{55}$ In this regard, Canadian Pharmacists Association suggested that the government should broaden the scope of practice for pharmacists with the provision of authority to execute the alternative plan autonomously and in collaboration with prescribers. Moreover, pharmacists must equip themselves with additional skills and expertise needed to cope with medicines shortages. ${ }^{56}$

A Pakistani study reported that shortage of particular brand of medicine was relatively high as compared with generics. ${ }^{34}$ We explored this issue and found some specific reasons and possible solutions of particular brand shortage. On questioning the respondents, they indicated that lack of traditional distribution system and consequent unlawful practices, including parallel trade, artificial shortage, grey market and selective distribution were the leading and hotly argued reasons of medicines shortages. The only reason behind this unethical practice is to earn high financial benefits at the cost of significant threat to health of patients. ${ }^{172157}$ Similar causes of medicines shortages were reported in European studies. ${ }^{39} 43$ Sudden increase in the demand was also indicated as one of the reasons of particular brand shortage by our study participants. A study appraising the medicines shortages in the UK and European countries also revealed that medicines shortages were triggered by unexpected fluctuation in demand. ${ }^{52}$ This sudden increase might be due to disease outbreak, promotional campaigns, catastrophic events, introduction of new product or therapeutic guidelines and artificial shortage. ${ }^{23} 3858$ According to this study, shortage of a particular brand was also highly influenced by the prescribing pattern. The stakeholders further exposed unethical promotional marketing strategies and incentives to be the reason of professional dishonesty. In Pakistani context, the pharmaceutical industries spend a lot of money on promotional strategies and the doctors are highly influenced by the incentives offered to them for prescribing a particular brand. ${ }^{59}$ A previous Pakistani study has also considered promotional influenced prescribing of particular medicine brand as one of the major barriers in the access to medicines. ${ }^{45}$ Production hurdles, including limited production capacity, production breakdown and 
Table 8 Theme 4: particular brand shortage issue

\begin{tabular}{|c|c|c|}
\hline Subtheme & $\begin{array}{l}\text { Categories and } \\
\text { subcategories }\end{array}$ & Quotations \\
\hline $\begin{array}{l}\text { Reasons of } \\
\text { particular } \\
\text { brand } \\
\text { shortage }\end{array}$ & $\begin{array}{l}\text { Lack of traditional } \\
\text { distribution system } \\
\text { and resulting } \\
\text { unlawful practices } \\
\text { including parallel } \\
\text { distribution, grey } \\
\text { marketing, illegal }\end{array}$ & $\begin{array}{l}\text { '... if the seasonal demand of certain medicine is increased then distributors stock that product and } \\
\text { they sell in black market by increasing rates ....and they also smuggle product in other district or other } \\
\text { country where they could get high rate so, some shortages are due to this reason.' (Regulator 11) } \\
\text { 'Provided that manufacturer has sufficient quantity of product available and they are willing to supply } \\
\text { to the market then distributors create artificial shortage of some high demand products and they attach } \\
\text { such products with some other low demand products. So due to this there artificial shortage of high } \\
\text { demand product is created.' (Regulator } 3 \text { ) }\end{array}$ \\
\hline
\end{tabular}
drug trafficking and artificial shortage

Sudden demand fluctuation due to seasonal effects or natural disasters

Marketing influenced prescribing

Production hurdles

Sole brand of drug

Voluntary recall due to quality and stability issues

\section{Solutions of Promotion} particular brand of traditional shortage distribution system and eradiation of parallel distribution, grey marketing, illegal drug trafficking and artificial shortage

Generic prescribing

Prompt new registration allotments

\begin{tabular}{|c|c|}
\hline \multirow{3}{*}{$\begin{array}{l}\text { Demand of } \\
\text { particular } \\
\text { brand by the } \\
\text { patients }\end{array}$} & $\begin{array}{l}\text { Preferred doctors' } \\
\text { prescription }\end{array}$ \\
\hline & $\begin{array}{l}\text { Patient's lack of } \\
\text { knowledge and } \\
\text { awareness }\end{array}$ \\
\hline & $\begin{array}{l}\text { Trust on brand } \\
\text { and psychological } \\
\text { acceptance }\end{array}$ \\
\hline \multirow{3}{*}{$\begin{array}{l}\text { Prescribing } \\
\text { of a particular } \\
\text { short brand } \\
\text { by doctors }\end{array}$} & $\begin{array}{l}\text { Influence of the } \\
\text { promotional } \\
\text { marketing strategies }\end{array}$ \\
\hline & $\begin{array}{l}\text { Reliability and } \\
\text { confidence on } \\
\text { particular brand }\end{array}$ \\
\hline & $\begin{array}{l}\text { Lack of information } \\
\text { about the shortages } \\
\text { of particular brand }\end{array}$ \\
\hline
\end{tabular}

'Sometimes there is disease outbreak due to some seasonal effects so the problem gets worse and the demand of the particular brand is increased.' (Distributor 7)

'Doctors have received money so they stick to one brand, due to which the demand of a particular brand increases and it gets short.' (Manufacturer 1)

'Production breakdown happens. If chemical manufacturing controls (CMC) are faulty and there is some issue or if there is any other safety reason because of which they have to stop the production or supply of medicine...' (Manufacturer 2)

'The reason of the particular brand shortage is when one company is manufacturing it...' (Regulator 8) 'Those drugs get short that don't have their 'me too' in the market means there are some drugs which are only manufactured by 1 or 2 companies. So the products manufactured by only one or two companies are mostly short...' (Regulator 8 )

'Often it also happens if there is some faulty batch then manufacturer recall it from the market and due this reason the brand gets short.' (Pharmacist 11)

'Government should make such rules and regulations, and should implement them to prevent illegal marketing. They should first of all seal the unregistered drugs and beside this they should find out the linkers of black market. And they should do strictness on manufacturer then black marketing would not be possible anymore. Because this happens when there is no supply from company, so who have had

stock, they start selling it on high prices.' (Regulator 2)

'There is a need to finish brand prescription and introduce generic. I think $90 \%$ of the problem will be resolved and this will be the best solution.' (Regulator 4)

'There are some products whose registration is granted to few companies and are short. Their registration must be granted to other manufacturers as well, so that there is healthy competition and shortage doesn't occur.' (Distributor 4)

'Actually patient normally uses that medicine which is prescribed to him by doctor. If they are prescribing a particular brand then normally patient sticks to that, although alternative products are available but unless prescriber will not change, he will definitely insist to buy that product.' (Regulator 3)

'They lack information that what is generic and what is brand, if you try to convince that this alternate is the same as prescribed by doctor then he still says that he exactly want that brand which is written by the doctor.' (Regulator 9)

'Obviously, if patient is using brand and he is comfortable and it is controlling his disease than this has psychological acceptance. He doesn't want to take risk.' (Manufacturer 2)

'Doctors take incentives from the companies. So they prescribe the brand of that company from whom they have received incentives. That's why they prescribe brands and don't go towards generics.' (Regulator 9)

'It is just a matter of confidence. Doctors have confidence on specific brand.' (Distributor 2)

'They don't know...companies don't tell them and the reason behind this is that when prescription run in the market then further demand is created and this is the actual requirement of the manufacturer to increase demand.' (Manufacturer 5) fault in the manufacturing chain were also frequently mentioned reasons of particular brand shortages in this study. In the USA, 168 products were listed short due to manufacturing issues. ${ }^{60}$ Multiple previous studies have reported manufacturing hurdles as one of the reasons of unavailability of medicine in the market. ${ }^{34383961}$ 


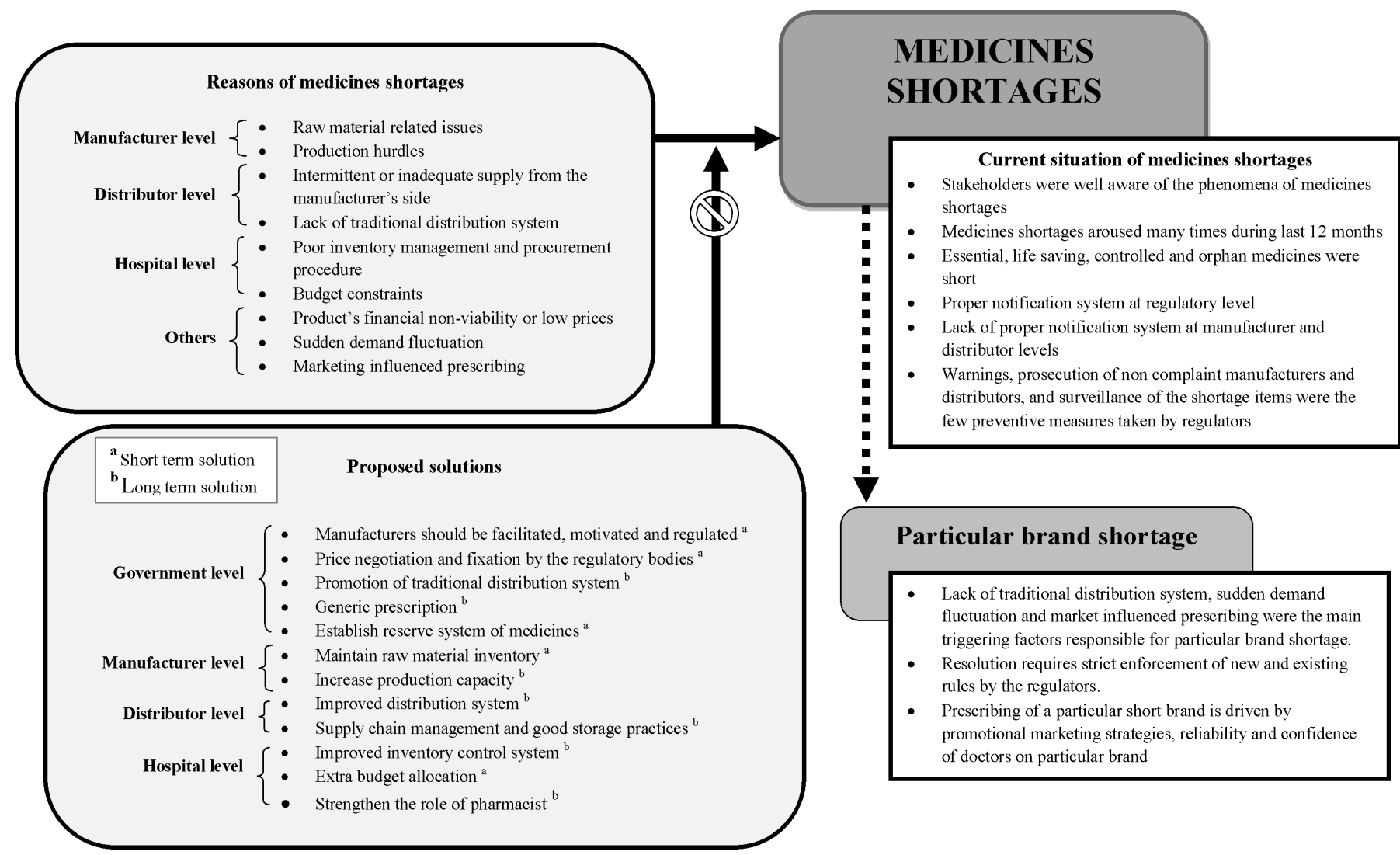

Figure 2 Summary of findings.

Stakeholders thought promotion of traditional distribution as a mandatory measure to prevent shortage of particular brand of medicine. The ASHP not only highlighted but emphasised the promotion of traditional distribution system through the establishment and implementation of guidelines and strict policies. ${ }^{23}$ Promotion and implementation of generic prescribing was also considered as one of the important solutions of particular brand shortages in Pakistan. However, implementation of generic prescribing and traditional distribution system could probably be the long-term solutions. The WHO suggested $100 \%$ generic prescribing to ensure access to medicines but recent Pakistani studies exposed that minimal drugs were prescribed by generic names. ${ }^{62} 63$ Although, in 1972, the Generic Drug Act was introduced in Pakistan to forbade the use of brand names and promote the use of generic names in prescriptions but the scheme operated until 1975, and generic marketing and prescribing was revoked by the government due to accelerated promotional activities and failure to bring down medicines prices. ${ }^{64}$ The government needs to reconsider the implementation of revised generic prescribing policy to prevent the shortage of particular brand of medicine.$^{25}$ According to our study participants, the major factor influencing patients to demand a particular brand was their preference to doctors' prescriptions (no substitution allowed). Similarly, with regard to doctors, promotional marketing strategies by the pharmaceutical manufactures, trust on specific brand and lack of doctor's trust on generics were main barriers to generic prescription that further aggravate possibility and severity of particular brand shortage. ${ }^{2565-67}$ A broad literature review and a Poland study have linked increased prescription rate of particular brand with the monetary benefits gained by practitioners from the pharmaceutical companies. ${ }^{656}$ Likewise, previous studies explained that prescribers were more inclined to prescribe a particular brand because they have concerns about the quality and efficacy of generic medicines and believed branded medicines to be superior than the generics. ${ }^{67}{ }^{68}$ Sharif $e t$ $a l$ also exposed that prescribers in Pakistan also favoured brand medicines and considered generics to be of inferior quality. ${ }^{59}$ To counter such type of misconceptions and ensure quality of generic drugs, the regulators in our study and the FDA recommended comparative biodissolution studies for the generic products in case bioavailability studies are not feasible. ${ }^{69}$

This study successfully appraised the situation regarding the medicines shortages in Pakistan but still has a few limitations. Although, wide range of stakeholders were involved but some important stakeholders such as patients and physicians were not included in the study. These were excluded because previous grey literature in Pakistan revealed that medicines shortages were mainly associated with regulatory and supply side hurdles and major stakeholders responsible for managing such issues were healthcare regulators and pharmaceutical manufacturers. ${ }^{30-32}$ Therefore, our focus was more 
towards exploring the reason and possible solutions of the medicines shortages from supply perspective which can be better addressed at the government and pharmaceutical manufacturing level. Beside this, distributors and pharmacists were included in the study because they were accountable for the medicines supply and management of inventories in both community and hospital settings. It is highly recommended that future research should include patients and physicians to better explore the consequences of medicines shortages and reasons from demand perspective. Other limitation of this study might be the potential bias and findings disparity associated with the employment a mix of phone and face-toface semistructured interviews because pharmaceutical manufactures only agreed for telephonic interviews due to their strict internal policies. However, to minimise the potential bias and ensure comparable outcomes, a complete respondent information pack (including interview schema) was provided to them before interview. As a result, we found that consented manufacturers were very comfortable and openly provided actual facts when they were assured of their anonymity.

\section{CONCLUSION}

Medicines were short in supply and this may have clinical and financial impact on the patients in Pakistan. Among the complex and multiple reasons of medicines shortages, the major reasons were shortage of API and raw material, non-traditional distribution tactics and sudden demand fluctuation. Among various proposed solutions of medicines shortages, the three most common solutions were to facilitate and regulate manufacturers, reasonable price fixation and improvements in the inventory control system. The main factors associated with shortage of particular brand of medicines were promotional influenced prescribing of a particular brand, doctor's trust on specific brand and patient preferences.

\section{IMPACT OF FINDINGS ON POLICY AND PRACTICE}

- The protocols regarding medicines shortages are quite inadequate in Pakistan. The findings of this thorough and objective research will be helpful for the policy makers in the development and pursuance of standard protocols, and short-term and long-term prevention strategies.

- Based on findings of this study, medicines shortages could be minimised by adopting short- and long-term strategies. Short-term resolution of medicines shortages could be achieved through facilitation, motivation and regulation of manufacturers, reasonable price fixation, establishment of reserve system of medicines, extra budget allocation by the government and maintenance of raw material inventory by the manufacturers. For long-term curbing of medicines shortages, the government needs to promote traditional distribution system, implement generic prescribing, establish improved inventory control system in hospitals and strengthen the role of pharmacist.

- After understanding the complete scenario of medicines shortages in Pakistan, a multifaceted collaborative institutional, societal and patient centred approach is recommended to successfully prevent medicines shortages.

- From research point of view, this study provides a strong base for the future multidimensional surveys to better quantify and further access the impact, underlying reasons and potential solutions of medicines shortages to provide continuous feedback to the policy makers.

Contributors Conceptualisation by MA and IMa; data curation by IMa; data analysis and interpretation by IMa, MA, IMu and SA; methodology by MA and IMa; supervision by MA; validation by MA; writing —original draft by IMa and SA; writing — review and editing by MA, IMu and IMa.

Funding The authors have not declared a specific grant for this research from any funding agency in the public, commercial or not-for-profit sectors.

Competing interests None declared.

Patient consent for publication Not required.

Ethical approval The study was approved by the Pharmacy Research Ethics Committee (PREC) at the Islamia University Bahawalpur (Reference: 32/S-2018-/ PREC, dated 31 May 2018). PREC approved verbal consent procedure.

Provenance and peer review Not commissioned; externally peer reviewed.

Data availability statement Anonymous interview transcripts will be shared upon receiving reasonable request. Please contact iramalik686@gmail.com.

Open access This is an open access article distributed in accordance with the Creative Commons Attribution Non Commercial (CC BY-NC 4.0) license, which permits others to distribute, remix, adapt, build upon this work non-commercially, and license their derivative works on different terms, provided the original work is properly cited, appropriate credit is given, any changes made indicated, and the use is non-commercial. See: http://creativecommons.org/licenses/by-nc/4.0/.

\section{REFERENCES}

1. Hogerzeil H, Mirta Z, World Health Organization. Access to essential medicines as part of the right to health. In: The world medicines situa-tion. 3rd edition. Geneva: World Health Organization, 2011.

2. Medicines shortages. Global approaches to addressing shortages of essential medicines in health systems. 30. Geneva: WHO Drug Information, 2016.

3. World Health Organization. Access to medicines: making market forces serve the poor, 2017. Available: http://www.who.int/ publications/10-year-review/medicines/en/

4. World Health Organization. Technical definitions of shortages and Stockouts of medicines and vaccines. Geneva: World Health Organization, 2017.

5. Food Drug Administration. Report on drug shortages for calendar year 2016; 2016

6. Morris S. Medicine shortages in Australia - what are we doing about them? Aust Prescr 2018;41:136-7.

7. American Society of Health-System Pharmacists. Drug shortages statistics. University of Utah Drug Information Service, 2018.

8. Donelle J. Assessing Canada's drug shortage problem. Canada: C.D. Howe Institute, 2018.

9. Tan YX, Moles RJ, Chaar BB. Medicine shortages in Australia: causes, impact and management strategies in the community setting. Int J Clin Pharm 2016;38:1133-41.

10. Yang C, Wu L, Cai W, et al. Current situation, determinants, and solutions to drug shortages in Shaanxi Province, China: a qualitative study. PLoS One 2016;11:e0165183.

11. Rosa MB, Reis AMM, Perini E. Drug shortage: a public health problem. Cad Saúde Pública 2016;32.

12. Schwartzberg E, Ainbinder D, Vishkauzan A, et al. Drug shortages in Israel: regulatory perspectives, challenges and solutions. Isr J Health Policy Res 2017;6:17. 
13. Casassus $B$. Europe urged to take action on drug shortages. The Lancet 2015;385:1279-80.

14. Gray A. Medicines shortages-unpicking the evidence from a year in South Africa. Australas Med J 2014;7:208-12.

15. Walker J, Chaar BB, Vera N, et al. Medicine shortages in Fiji: a qualitative exploration of stakeholders' views. PLoS One 2017;12:e0178429.

16. Bocquet $F$, Degrassat-Théas $A$, Peigné J, et al. The new regulatory tools of the 2016 health law to fight drug shortages in France. Health Policy 2017:121:471-6.

17. Fox ER, Birt A, James KB, et al. ASHP guidelines on managing drug product shortages in hospitals and health systems. Am J Health Syst Pharm 2009;66:1399-406.

18. Ventola CL. The drug shortage crisis in the United States: causes, impact, and management strategies. Pharm Ther 2011;36.

19. Pauwels K, Huys I, Casteels M, et al. Drug shortages in European countries: a trade-off between market attractiveness and cost containment? BMC Health Serv Res 2014;14:438.

20. McLaughlin M, Kotis D, Thomson K, et al. Effects on patient care caused by drug shortages: a survey. J Manag Care Pharm 2013;19:783-8.

21. Haninger K, Jessup A, Koehler K. Economic analysis of the causes of drug shortages. ASPE Issue Brief, 2011: 1-19.

22. De Weerdt E, De Rijdt T, Simoens S, et al. Time spent by Belgian Hospital pharmacists on supply disruptions and drug shortages: an exploratory study. PLoS One 2017;12:e0174556.

23. Fox ER, McLaughlin MM. ASHP guidelines on managing drug product shortages. Am J Health Syst Pharm 2018;75:ajhp180441:1742-50.

24. Khan AA. Budget in Brief 2018-19 - Ministry of Finance. M.o. finance, Editor, 2018.

25. Atif M. Pharmaceutical policy in Pakistan, in pharmaceutical policy in countries with developing healthcare systems. Springer, 2017: 25-44.

26. Kumar S, Bano S. Comparison and analysis of health care delivery systems: Pakistan versus Bangladesh. J Hosp Med Manage 2017;3:1-7.

27. Amin T. 11 foreign pharmaceutical companies closed business, Senate body told. In: Business recorder, 2013.

28. Rashid $\mathrm{H}$. Impact of the drug regulatory authority Pakistan: an evaluation. . New Visions for Public Affects, 2015: 7. 50-61.

29. Kharal A. Bad medicine: Over 450 pharmacies selling spurious drugs in Lahore. In: The Express Tribune with the International New York Times, 2013.

30. Nizami A. Hepatitis patients suffer due to medicine shortage across province. In: Pakistan today. Karachi, 2017.

31. DAWN. Drug shortage. In: DAWN. Pakistan, 2017.

32. Kazi AN, Mohiuddin H. Pakistan is hit by a shortage of antituberculosis drugs. BMJ 2016;353:i2510.

33. Dunya New. Medicines in shortage as escalating prices affect supply. In: Dunya New, 2016.

34. Fatima SA, Khaliq A. A survey regarding drug shortage in tertiary care hospitals of Karachi, Pakistan. J Pharm Pract Commun Med 2017;3:262-6.

35. Besancon L, Chaar B. Report of the International Summit on medicines shortage. Toronto, Canada: International Pharmaceutical Federation, 2013.

36. Junaidi I. Pharma industry blames regulator for medicine shortage. In: DAWN. Pakistan, 2016

37. Ahmad A. Concern over high demand for ephedrine in Pakistan. In: DAWN. Pakistan, 2018.

38. Heiskanen $\mathrm{K}$, Ahonen $\mathrm{R}$, Kanerva $\mathrm{R}$, et al. The reasons behind medicine shortages from the perspective of pharmaceutical companies and pharmaceutical wholesalers in Finland. PLOS One 2017;12:e0179479.

39. Bogaert P, Bochenek T, Prokop A, et al. A qualitative approach to a better understanding of the problems underlying drug shortages, as viewed from Belgian, French and the European Union's perspectives. PLoS One 2015;10:e0125691.

40. Hennink MM, Kaiser BN, Marconi VC. Code saturation versus meaning saturation: how many interviews are enough? Qual Health Res 2017;27:591-608.

41. Sialubanje C, Massar K, Hamer DH, et al. Reasons for home delivery and use of traditional birth attendants in rural Zambia: a qualitative study. BMC Pregnancy Childbirth 2015;15:216.

42. Silverman D. Doing qualitative research: a practical Handbook. SAGE Publications Limited, 2013.
43. Pauwels K, Simoens S, Casteels M, et al. Insights into European drug shortages: a survey of hospital pharmacists. PLoS One 2015;10:e0119322.

44. De Weerdt E, Simoens S, Casteels M, et al. Toward a European definition for a drug shortage: a qualitative study. Front Pharmacol 2015;6:253

45. Zaidi S, Bigdeli M, Aleem N, et al. Access to essential medicines in Pakistan: policy and health systems research concerns. PLoS One 2013;8:e63515.

46. Shabbir Hussain. DRAP approves $15 \%$ increase in medicine prices. In: The Express Tribune. Pakistan, 2019.

47. Drug Regulatory Authority of Pakistan. Controlled drugs division. Available: https://www.dra.gov.pk/Home/ControlledDrugs [Accessed 1 March 2019].

48. Magadzire BP, Ward K, Leng HMJ, et al. Inefficient procurement processes undermine access to medicines in the Western Cape Province of South Africa. S Afr Med J 2017;107:581-4.

49. Callender C, Grasman SE. Barriers and best practices for material management in the healthcare sector. Eng Manag $J$ 2010;22:11-19.

50. Gupta U, Ramesh A. Analyzing the barriers of health care supply chain in India: the contribution and interaction of factors. Procedia Soc Behav Sci 2015;189:217-28.

51. World Health Organization. 16. Geneva: WHO Drug Information, 2002.

52. Birgli. An evaluation of medicines shortages in Europe with a more in-depth review of these in France, Greece, Poland, Spain, and the United Kingdom. Switzerland: European Association of Europharmaceutical companies (EAEPC), 2013.

53. Food and Drug Administration. Strategic plan for preventing and mitigating drug shortages. United States: U.S. Food and Drug Administration, 2013.

54. Lee KS, Shahidullah A, Zaidi STR, et al. The crux of the medicine prices' controversy in Pakistan. Front Pharmacol 2017:8: :504.

55. Ahmed A, Tanveer M, Siddiqui A, et al. Bridging the gap for clinical pharmacist in developing countries like Pakistan. $J$ Coll Physicians Surg Pak 2018;28:229-32.

56. Canadian Pharmacists Association. Canadian drug shortages survey: final report. Ottawa: Author, 2010.

57. Food Drug Administration. A review of FDA's approach to medical product shortages. 31. FDA Report, 2011.

58. Government Accountability Office. Public health threat continues, despite efforts to help ensure product availability. Washington, DC: United States Government Accountability Office, 2014: 14-194.

59. Sharif $\mathrm{H}$, Sharif $\mathrm{S}$, Zaighum I. Reasons of brand switching and preference in prescription medicines: a comparison between physicians and pharmacists of karachi. . The Pharma Innovation, 2016: 5(7, Part B). 99.

60. Birgli. An evaluation of medicines shortages in Europe with a more in-depth review of these in France, Greece, Poland, Spain, and the United Kingdom; 2013.

61. Bogaert P, Prokop A, Bochenek T. Prevention and management of medicine shortages in Belgium, France and from the perspective of the European Union. Value Health 2014;17:A412.

62. Atif M, Azeem M, Rehan Sarwar M, et al. Evaluation of prescription errors and prescribing indicators in the private practices in Bahawalpur, Pakistan. J Chin Med Assoc 2018;81:444-9.

63. Atif M, Sarwar MR, Azeem M, et al. Assessment of WHO/INRUD core drug use indicators in two tertiary care hospitals of Bahawalpur, Punjab, Pakistan. J Pharm Policy Pract 2016;9.

64. Jamshed SQ. The pharmaceutical industry, intellectual property rights and access to medicines in Pakistan. In: The new political economy of pharmaceuticals. Springer, 2013: 167-84.

65. Wazana A. Physicians and the pharmaceutical industry: is a gift ever just a gift? JAMA 2000;283:373-80.

66. Makowska M. Polish physicians' cooperation with the pharmaceutical industry and its potential impact on public health PLoS One 2017;12:e0184862.

67. Colgan S, Faasse K, Martin LR, et al. Perceptions of generic medication in the general population, doctors and pharmacists: a systematic review. BMJ Open 2015;5:e008915.

68. Khadke VV, Khanda SY. To study doctor's beliefs, barriers, awareness, and actual practices regarding use of generic medicines. Int J Basic Clin Pharmacol 2017;6:1871-9.

69. Anand O, Yu LX, Conner DP, et al. Dissolution testing for generic drugs: an FDA perspective. AAPS J 2011;13:328. 